ISSN: 0213-2079 - ISSN electrónico: 2386-3889

DOI: https://doi.org/10.14201/shhmo20184023162

\title{
PROFESIONES RELIGIOSAS FORZADAS Y ESTRATEGIAS JUDICIALES: SOR ANNA MADDALENA VALDINA*
}

\section{Unwilling Vows and Judicial Strategies: Sister Anna Maddalena Valdina}

Giovanna FIUME

Università di Palermo

Correo-e: giovannafiume@gmail.com

RESUMEN: En 1640, Anna, hija del príncipe de Valdina, fue ingresada en un convento de Palermo junto con sus tres hermanas. Tenía siete años y permanecería allí hasta 1699. Pidió primero a su padre y luego a su hermano abandonar el estado monástico al que fue forzada por razones patrimoniales y al que nunca se resignó. Su historia se inscribe dentro del fenómeno de las llamadas profesiones religiosas forzadas, que el Concilio de Trento había intentado remediar. A la muerte de su hermano en 1693, Anna, que entonces contaba sesenta años, solicitó al arzobispo de Palermo que le concediera la nulidad de sus votos y le permitiera volver a la condición seglar. De ese modo comenzó una seria disputa que desencadenó un violento conflicto jurisdiccional entre los tribunales civiles y religiosos, la Congregación de Obispos del Vaticano y las magistraturas sicilianas, y que acabó llegando hasta el rey de España y el pontífice. La excepcionalidad de este caso radica en la posibilidad de contextualizarlo minuciosamente, gracias a la rica documentación de archivo producida por esa causa judicial, a la intervención de diferentes magistrados e instituciones, seculares y eclesiásticas, y de numerosos actores sociales (desde la simple monja al virrey). En el curso de ese proceso, Anna escribió numerosos memoriales

* Este trabajo se enmarca dentro del Proyecto de Investigación HAR2014-53802-P, financiado por el MINECO. Traducción del italiano de Nuria Verdet Martínez. 
que revelan sus estrategias judiciales, su lógica nobiliaria y otros aspectos de su enérgica personalidad.

Palabras clave: profesiones religiosas forzadas; conventos femeninos; estrategias aristocráticas; conflictos jurisdiccionales.

ABSTRACT: In 1640 Anna, daughter of the prince of Valdina, was put into a convent in Palermo along with three sisters. She was seven years old and would remain there until 1699. She first asked her father and then her brother to leave the monastic state to which she was forced for patrimonial reasons and to which she never resigned herself. Her story is inscribed within the phenomenon of the so-called forced monacations, to which the Council of Trent had tried to remedy. On the death of her brother, in 1693, Anna, about sixty years old, asked the archbishop of Palermo to grant the nullity of her religious profession and her return to the lay state. Thus began a very severe judicial dispute that triggers a violent jurisdictional conflict between ecclesiastical and secular magistracies, the Vatican Congregation of Bishops, the Sicilian magistracies and ends up reaching the king of Spain and the pope. The exceptionality of the case-study lies in the possibility of its close contextualization, thanks to the rich archival documentation produced by that judicial litigation, to the intervention of different magistrates and institutions, secular and ecclesiastical and numerous social actors (from the simple nun to the viceroy). In the course of this litigation, Anna produced numerous memorials that reveal her judicial strategies, her noble logic and other aspects of her volatile personality.

Key words: unwilling wows; female convents; aristocratic strategies; jurisdictional conflicts.

\section{UN MECANISMO INVENTADO POR LA SOBERBIA PATERNA}

El fenómeno de los monacatos forzosos es conocido hasta el punto de haberse convertido durante siglos en tema literario ${ }^{1}$. Los historiadores lo remontan a las

1. Diderot, Denis: La religieuse. París, Librairie A. Lemerre, 1925; Manzoni, Alessandro: I promessi sposi. Milán, Mondadori, 2009; Giovanni Verga: Storia di una capinera. Milán, Feltrinelli, 2001; Zorzi, Alvise: La monaca di Venezia. Una storia d'amore e di libertà. Milán, Mondadori, 1996. 
estrategias familiares de la aristocracia católica que, adoptando la institución del mayorazgo y del fideicomiso para mantener la integridad del patrimonio, transmitido junto al título nobiliario al primogénito, destinan a los varones menores (los segundones) al celibato. Además, a causa del aumento de las dotes, muchas chicas nobles son destinadas, bien a inconvenientes matrimonios hipógamos o bien al celibato en los monasterios; entre estas, las menos bellas y virtuosas, es decir, «las más feas, las enfermizas, las ilegítimas, las que en definitiva no habrían encontrado fácilmente un partido para casarse» ${ }^{2}$. Del mismo modo, los segundones son conducidos a la carrera militar o a la eclesiástica, más abierta al mundo que la reclusión en el claustro permitida a las mujeres. La libre elección del compañero implicaría una circulación no regulada de los patrimonios; de ahí la necesidad de la transmisión patrimonial de acuerdo a estrictas lógicas familiares -entre las cuales las elecciones matrimoniales son cruciales-, personificadas en la voluntad del cabeza de familia que impone la obediencia de los hijos, educados en la sumisión hasta el temor reverencial. El despotismo paterno, con la cómplice colaboración de madres y hermanos, se ejercita bien en los casos de vocaciones sinceras de herederos y primogénitos, bien en aquellos de rechazo manifiesto a profesar los votos monásticos. «De padres y de familias enteras en guerra contra las elecciones de los jóvenes está llena la tradición de los relatos de vocación» ${ }^{3}$.

Seleccionar al mejor heredero -hay también casos de primogénitos destinados al convento- $y$, sobre todo, reducir el número, hace de la profesión forzada un «mecanismo inventado por la soberbia paterna» ${ }^{4}$ que llena los conventos de desheredados: es habitual hacer firmar la renuncia a los bienes familiares antes de pronunciar los votos. Anne Jacobson Schutte entre 1668 y 1793 ha encontrado 978 casos de recurso a la Congregación romana de los obispos y de los regulares para el reconocimiento de la nulidad de la profesión; se trata de 807 hombres y 171 mujeres, procedentes de toda la Europa católica (en su mayoría de los Estados pontificios, de Nápoles, de España y de Portugal), en menor medida de estados, como Venecia, donde el gobierno, celoso de su propia jurisdicción, prohíbe dirigirse a la Santa Sede 5 .

2. «Las cojas, jorobadas, lisiadas o simples [...] son condenadas a estar presas todo el tiempo de su vida», así Tarabotti, Angela: Inferno monacale, en Francesca Medioli: L' Inferno monacale» di Arcangela Tarabotti. Turín, Rosenberg \& Sellier, 1990, pp. 111-112. «Los monasterios sirven de sentina de barco, donde tiran toda la inmundicia y se vanaglorian de ofrecer un sacrificio, incluso cuando envuelven de velos sagrados a sus hijas, concebidas ilegítimamente y frecuentemente nacidas de un adulterio». Ead.: La semplicità ingannata. Ed. crítica editada por Simona Bortot, Padua, Il Poligrafo, 2007, p. 228.

3. Prosperi, Adriano: La vocazione. Storie di gesuiti tra Cinque e Seicento. Turín, Einaudi, 2016, p. 149.

4. Tarabotti: La semplicità ingannata, cit., p. 255.

5. Jacobson Schutte, Anne: «Between Venice and Rome: the Dilemma of Involuntary Nuns», Sixteenth Century Journal, XLI/2, 2010, pp. 415-439. El tema ha sido más ampliamente 
Los padres -avaro, soberbio, ignorante define Alessandro Manzoni al de la monja de Monza- transforman los monasterios en depósitos para solteronas expulsadas del mercado matrimonial que, desde jóvenes, representan un peligro para el honor de las familias y, al envejecer, un peso inútil. Por el contrario, «en un monasterio una chica estaba segura [...]; significaba darle un estatus respetable y colocarla para siempre» ${ }^{6}$. Además, los conventos reproducen la jerarquía social: las nobles (religiosas de coro), destinadas a la carrera de abadesa, vicaria (o priora), camarlenga y cillerera (ecónoma), se dedican al canto, al bordado y a los ejercicios religiosos en la iglesia y en el claustro, al cuidado del jardín; a las plebeyas (legas) se confían los trabajos menos gratificantes; por último, las siervas (massare) son laicas al servicio de una única monja o del monasterio y desarrollan el trabajo manual. La presencia en los claustros de tantas chicas nobles, que han profesado sin vocación, incluso ignorantes de las obligaciones de la vida religiosa, hace que la autoridad secular y eclesiástica permita

«en el vivir, en la obediencia y en el vestir todas aquellas comodidades [desde la calidad de las sábanas y de los colchones, de la comida y de la propia ropa] para que vivieran si no más consoladas, al menos un poco menos descontentas -escribe el patriarca de Venecia en 1619-; estas son nobles, criadas y educadas con suma delicadeza y respeto, que si fueran del otro sexo a ellas les tocaría el gobernar y dirigir el mundo» ${ }^{7}$.

Los locutorios de los conventos venecianos se abren a la conversación con padres y extraños, la correspondencia no es controlada, la música y el canto no celebran solo acontecimientos religiosos. En Milán, como en Venecia, tampoco se consigue erradicar los abusos (las «vanidades»), aunque sean condenados numerosas veces (camas con dosel, prendas de vestir seculares, objetos de plata, imágenes preciosas, perritos, dados y naipes, música y teatro para el público visitante). Una clausura poco rigurosa y una descuidada observancia de las reglas son agradecidas por las familias nobles por hacer el convento más aceptable a sus hijas y debemos esperar al Setecientos para una reforma seria de estas costumbres, en paralelo a la reducción de las vocaciones nobiliarias y a la mayor libertad dejada a las hijas ${ }^{8}$.

desarrollado en Ead. By Force and Fear. Taking and Breaking the Monastic Vows in Early Modern Europe. Ithaca y Londres, Cornell University Press, 2011.

6. Tarabotti: L'inferno monacale, cit., p. 113. Medioli, Francesca: «Lo spazio del chiostro: clausura, costrizione e protezione nel XVII secolo», en Silvana Seidel Menchi, Anne Jacobson Schutte, Thomas Kuehn (ed.): Tempi e spazi di vita femminile tra Medioevo ed età moderna. Bolonia, Il Mulino, 1999.

7. Tarabotti: L'inferno monacale, cit., p. 120.

8. Vismara Chiappa, Paola: Per vim et metum. Il caso di Paola Teresa Pietra. Como, Litografia New Press, 1991, pp. 9-33. Dante Zanetti muestra cómo los aristócratas milaneses nacidos 
Finalmente, los lazos que unen a las monjas con las familias de origen, cuyo sostén económico es esencial para la vida del monasterio, «encuentran escasa limitación en la clausura: princesas y nobles pueden alojarse un día o durante un período más largo; viudas y mujeres que se encuentran en situaciones familiares particulares encuentran refugio en los monasterios» ${ }^{9}$, donde grupos de mujeres emparentadas entre sí (así mejor) se muestran activas al influir en decisiones familiares, negociar crisis conyugales, orientar elecciones matrimoniales ${ }^{10}$; $"$ monjas y abadesas no desdeñan amistades con señores de la buena sociedad» ${ }^{11}$ y los admiten en clausura con todo su séquito.

\subsection{Traicionadas, casi podría decirse, durmiendo...}

El 3 y el 4 de diciembre de 1563, el concilio de Trento decretaba nuevas reglas para garantizar el ingreso voluntario en religión de las jóvenes: en su última sesión los padres conciliares se pronunciaban a favor del consentimiento, no solo en la profesión religiosa, sino de acuerdo con el decreto Tametsi también en el matrimonio, produciendo un cambio radical con la sustracción de ambos -la elección del monasterio es un matrimonio místico por el cual era necesaria una dote- a la autoridad del pater familias y valorando la libertad de la elección individual ${ }^{12}$. El caput $X V$ del Decretum de regularibus et monialibus establecía la edad mínima para la profesión solemne a los dieciséis años completos; el caput XVII, la exploración formal de la voluntad de los candidatos en una entrevista privada con el obispo; el caput XVIII fulminaba el anatema por el cual se forzaba la voluntad per vim et metum de quien quería tomar los votos y de quien los rechazaba; el

entre 1650 y 1699 destinan el $22 \%$ de sus propios hijos varones y el 30,5\% de las mujeres al convento; entre los padres nacidos desde 1700 hasta 1749 el porcentaje desciende respectivamente al 12,8 y al 13\%. En consecuencia los quincuagenarios solteros de la nobleza milanesa son el $56 \%$ entre 1650 y 1699 , frente al $48,5 \%$ de las solteras, el $50,5 \%$ en los cincuenta años siguientes (el $34,5 \%$ las solteras) y el $36,5 \%$ entre 1750 y 1799 (el $13 \%$ las solteras). El desplome de las tasas de soltería entre los hombres y mujeres, pero especialmente entre estas últimas, indica la tendencia de las mujeres a acceder al matrimonio y produce un brusco descenso de las vocaciones monásticas. Zanetti, Dante E.: «La demografia del patriziato milanese nei secoli XVII, XVIII, XIX», Anales Cisalpines d'bistoire sociale, II serie, n. 2, 1972.

9. Zarri, Gabriella: Recinti. Donne, clausura e matrimonio nella prima età moderna. Bolonia, Il Mulino, 2000, p. 98.

10. Borello, Benedetta: Trame sovrapposte. La socialità aristocratica e le reti di relazione femminili a Roma (XVII-XVIII secolo). Nápoles, ESI, 2003.

11. Lirosi, Alessia: I monasteri femminili a Roma tra XVI e XVII secolo. Roma, Viella, 2012, p. 255.

12. Cfr. Zarri: Recinti, cit., en particular cap. III, Il matrimonio tridentino, pp. 203-250; Lombardi, Daniela: Storia del matrimonio dal Medioevo a oggi. Bolonia, Il Mulino, 2008 y la ágil síntesis de Prosperi, Adriano: Il Concilio di Trento. Turín, Einaudi, 2001. 
caput XIX preveía en el caso de profesión forzada la posibilidad de recurrir durante los primeros cinco años desde la profesión ${ }^{13}$. El Papa delegaba estos casos a la Congregación del concilio, instituida en 1564, y desde 1601 a la Congregación de los obispos y de los regulares. El procedimiento preveía que, recibida una petición de reconocimiento de la nulidad de los votos monásticos, el Papa ordenase al obispo de la diócesis competente que instruyese un proceso y escuchase a los testigos. La transcripción del proceso debía ser enviada a la Congregación romana que decidía sobre la cuestión; cuando la decisión fuera favorable, el Papa emitía un decreto de restitución al estado laico y la Congregación pedía al ordinario que decretase la nullitas professionis. En nuestro caso veremos cómo este procedimiento, que equilibra hábilmente la autoridad del ordinario de la sede local con el poder de decisión de la Santa Sede, será desbaratado por las prerrogativas y por los privilegios de las magistraturas sicilianas.

De manera más general, el concilio se ocupaba de la residencia de los obispos en sus sedes, de la convocatoria regular de los sínodos y de las visitas pastorales, de la formación de los sacerdotes en los seminarios, de la reforma de los monasterios, con particular consideración a la clausura. No será fácil imponer un rígido control contra la laxitud de las costumbres de seculares y regulares, que cambiarán muy lentamente. Hay una fuerte resistencia de las mujeres profesas y de las familias a las que se les hacen más austeras las reglas de la vida claustral y sobre todo de la clausura: «Se hizo apremiante el temor de no poder ya obligar fácilmente a las hijas a tomar el velo, donde las condiciones fuesen demasiado rigurosas» ${ }^{14}$. Giovanna Paolin ha documentado el malestar de las monjas, seguido de actitudes de resistencia, de abierta rebelión contra las autoridades eclesiásticas y de lenta adaptación; muchas continuaron considerando las reglas monásticas como formalidades sin valor vinculante para quien no había consentido libremente la profesión.

La veneciana sor Arcangela Tarabotti bien puede acusar de complicidad a los padres (la alianza entre padre y madre en primer lugar), a la Iglesia (abadesas y confesores) y al poder temporal (los padres de la República), convirtiendo audazmente la cuestión en un problema político al que echar la culpa de la degeneración de la vida en los conventos. Solo algunas -porque muchísimas ignoran la existencia de esta posibilidad- emprenden el arduo, largo y costoso procedimiento judicial para la nulidad de la profesión religiosa; otras se resignan sin dejar a los historiadores huellas documentales de su trayectoria biográfica; de algunas conocemos la

13. Alberigo, Giuseppe et al. (ed.): Conciliorum Ecumenorum Decreta. Bolonia, Dehoniane, $1991^{3}$, pp. 781-782.

14. Paolin, Giovanna: Lo spazio del silenzio. Monacazioni forzate, clausura e proposte di vita religiosa femminile nell'età moderna. Pordenone, Edizioni Biblioteca dell'Immagine, 1996. 
evidente rebelión, individual o colectiva ${ }^{15}$, los gestos destructivos contra las cruces, hostias, imágenes sacras, difíciles de calificar como locura o posesión diabólica para las autoridades eclesiásticas ${ }^{16}$ y que expresan el malestar de la clausura, hasta el gesto extremo del suicidio. Pocas tienen éxito en la difícil empresa de la fuga. ¿Qué podían, por otra parte, esperarse las mujeres que volvían al siglo después de los años pasados en el monasterio? Abandonadas por la familia, habrían debido ganarse la vida con el trabajo de sus propias manos, al que no estaban acostumbradas y que consideraban deshonroso para las aristócratas; habrían tenido que mendigar el pan a parientes que se sentían deshonrados por su comportamiento; el concubinato o la prostitución amenazaban a las jóvenes monjas fugitivas sin la garantía de un matrimonio inmediato que las pusiese bajo la protección de un hombre. Para abandonar de un modo u otro el monasterio era necesario coraje, apoyo moral y financiero, una red de solidaridad.

Los confesores asumen la tarea de hacer razonar a la «novicia contra su voluntad?», de hacerle aceptar la voluntad de Dios que, por caminos tortuosos, como el desamor de los padres y el interés de los hermanos, ha demostrado haberla querido, y proponen hacer de la necesidad virtud, aceptando de buen grado la comodidad de una vida regulada, sostenida por la amistad y por la caridad de las correligionarias, que garantizan la asistencia en las enfermedades, la satisfacción de las necesidades de alimento, vestido y habitación, porque la vida religiosa es la más quieta y la más cómoda y por tanto la más feliz de todas ${ }^{17}$. Se silencian «las tensiones típicas de la vida claustral: las enemistades, la rivalidad y la hostilidad» ${ }^{18}$, que caracterizan frecuentemente las relaciones entre hermanas.

15. En 1664 el obispo de Macerata, respaldado por la Sacra Congregación de los obispos y de los regulares, excomulga a dos hermanas del convento de Santa Catalina que coquetean con dos jóvenes; las hermanas, capitaneadas por la superiora, como protesta infringen la clausura y arrancan de la puerta los edictos de la autoridad religiosa, apoyadas por el Consejo de la ciudad. El obispo lanza un interdicto y excomulga a un segundo convento que ha imitado la protesta; el escabroso asunto se aplaca algunos meses más tarde. Así Piangatelli, Gualberto: «La forzata scelta della vita ecclesiastica o religiosa nei secoli XVI-XVIII e l'atteggiamento della Chiesa locale», en AA. VV., La nobiltà della Marca nei secc. XVI-XVII. Patrimoni, carriere, cultura. Macerata, Centro di studi storici maceratesi, 1998, p. 113.

16. Véase el extraordinario proceso del Santo Oficio contra sor Mansueta del convento de Santa Cruz, 1574, en Milán, L'ossessione secolare di suor Mansueta, cit. y en el apéndice a Paolin, Lo spazio del silenzio, cit., pp. 169-196 y el cap. Il malcontento, íbidem, pp. 55-75.

17. Calino, Cesare, SJ: Discorsi scritturali e morali ad utile intrattenimento delle monache. Venecia, 1707, pp. 41, 53.

18 Laven, Mary: Monache. Vivere in convento nell'età della Controriforma. Bolonia, Il Mulino, 2004, p. 105. 


\subsection{Anna Valdina, monaca nulliter professa}

El 20 de octubre de 1693, sor Anna Maddalena Valdina, profesa en el monasterio delle Stimmate [de las llagas] de San Francisco de la ciudad de Palermo, envía un Memoriale ${ }^{19}$ al obispo de la ciudad, Ferdinando Bazán, en el que recuerda su condición de monja a la fuerza: hija de Andrea Valdina y del Bosco, príncipe de la Rocca, donde nace el 26 de julio de 1635, en 1642, a la edad de siete años, junto a sus hermanas Laura y Caterina, había sido metida como educanda en el monasterio palermitano de San Juan del Origlione; solo Paola, la mayor, se había salvado y había permanecido en la casa paterna de la Rocca. Después de «disgustos» entre el padre y los superiores de este convento, «no habiendo querido profesar, las niñas fueron sacadas y puestas en la Abadía y Anna no quiso entrar y fue metida en la casa de la princesa de la Scaletta [hermana del padre], para que la obligase y forzase a hacerse monja» ${ }^{20}$. De nuevo, después de «peleas» entre la tía y el padre, la niña es trasladada junto con una tía abuela paterna, la baronesa Mazzarrone, con quien también se producen «disgustos», porque Anna contradecía el plan del padre y, a pesar de la edad infantil y de las amenazas, «ella persistía en su obstinación» ${ }^{21}$. En realidad una norma tridentina exigía que, antes de pronunciar los votos, para verificar la vocación, la novicia dejase durante seis meses el convento y volviese a la vida en familia. Podemos imaginar que la tía y la tía abuela habían intentado hacer razonar a la joven sobrina, la cual siempre repetía que «Dios nuestro Señor no le había dado espíritu para entrar en religión y que quería permanecer seglar y porque el dicho su padre la obligaba a hacerse monja, la dicha doña Anna llorando respondía que no quería hacerse $»^{22}$. La apremiante, amenazante insistencia del padre finalmente la «redujo por la fuerza ${ }^{23}$, a pesar de los lloros y de las negativas de Anna; entra así en el monasterio delle Stimmate «por el miedo reverencial y las amenazas hechas por el dicho su padre», que le negaba lo necesario y la amenazaba con convertirla en «esclava eterna» y con quererla «descuartizar con sus propias

19. Memoriale all'Arcivescovo di Palermo del 20 de octubre de 1693, en Archivio di Stato di Palermo (en adelante ASPa), Archivio Papè Valdina, Scritture collette nel Tribunale della Regia Monarchia sopra la nullità della professione dell'Ill.ma Donna Anna Valdina, principessa di Valdina, vol. 164, cc. 1r.-v.

20. Restitutiones Capitula et Jura di Anna Valdina contro suor Giuseppa Margherita Lucchese badessa delle Stimmate e il principe Pietro Filangieri, protettore del monastero, ibidem, vol. 164, c. $48 \mathrm{r}$.

21. En la Raccolta dei testimoni del 28 de febrero de 1695 lo declara Flavia Leto, camarera de la princesa de Mazzarrone, en aquel momento de quince años de edad, que dormía con Anna, de once años, íbidem, vol. 164, c. 61r.

22. Memoriale, íbidem, vol. 164 , c. 5 r.

23. Restitutiones Capitula et Jura, cit., vol. 164, c. 50v. 
manos» ${ }^{24}$. Tenía catorce años cuando capituló, «hija de tierna edad, y sin ningún amparo, y carente de cualquier ayuda y protección» ${ }^{25}$. Tomó el hábito entre lágrimas, «sin espíritu ni vocación» ${ }^{26}$ y no perdía ocasión alguna de confirmar su voluntad de no pronunciar los votos y de dejar el convento; a tales afirmaciones en el locutorio el padre respondía frecuentemente con terribles amenazas de «hacerla vivir de la mendicidad», de hacerla morir de hambre, de rebajarla a esclava de las otras monjas ${ }^{27}$. Anna se equivocaba pensando que el padre capitularía antes o después ante su obstinación; por el contrario «cada vez que iba a las rejas [en el locutorio] el padre se enfadaba» ${ }^{28}$, «muy disgustado y con la cara ardiendo» ${ }^{29}$; monjas y visitantes la oían sollozar y, dice una hermana, «era una lástima ver a doña Annuzza a quien forzaban a hacerse monja [...] y se había convencido como quienes suben las escaleras de la horca» ${ }^{30}$.

El 30 de junio de 1695, la tía de Anna, Vittoria Valdina del Bosco, de setenta y siete años, hermana del príncipe Andrea, en el trascurso de su declaración ante la corte arzobispal, cuenta cómo su hermano había metido a la hija en el convento, a pesar de la aversión de la niña hacia la vida religiosa y cómo la había después trasladado temporalmente a casa de su hermana sin ser capaz de someter su voluntad; «finalmente, viendo la obstinación de la hija, pasó a amenazas más estrictas», entre ellas la de dejarla morir en las tierras de la Rocca ${ }^{31}$. Y Anna, asustada por el padre, «hombre terrible, y que cumplía las amenazas que hacía, se vio obligada por fuerza a entrar en el monasterio delle Stimmate y siempre ha reclamado y ha dicho públicamente haber sido hecha monja a la fuerza» ${ }^{32}$. El libro de las profesiones monásticas delle Stimmate informa de que Anna «el 25 de julio de 1648 tomó el hábito y se puso el nombre de sor Maria Maddalena» ${ }^{33}$; tres años después, el 19 de septiembre de 1651, profesó. Tenía dieciséis años, la edad canónica (la testigo erróneamente le atribuye doce). El día de la ceremonia, lloraba de manera incontenible y se oyó a su abuelo Pietro, a quien la niña le pedía ayuda, responder: «Hija, no

24. Restitutiones Capitula et Jura, cit., vol. 164 , c. 52r.

25. Íbidem, c. 52r.

26. Íbidem, c. 52v.

27. «Todos los gastos personales de las monjas eran sufragados por sus familias, que las abastecían de comida, ropa y dinero, pagaban al médico y al especiero y en algunos casos las dotaban de una criada». Paolin: Lo spazio del silenzio, cit., p. 35.

28. Memoriale, vol. 164 , c. $5 \mathrm{v}$.

29. Pietro Analeo, Raccolta dei testimoni, cit., vol. 164, c. 63r.

30. Íbidem, c. $63 \mathrm{v}$.

31. Vol. 165 , c. $181 \mathrm{r}$.

32. Vol. 165 , c. $181 \mathrm{v}$.

33. ASPa, Corporazioni religiose soppresse, Monastero delle Stimmate, vol. 70, cit. en Salamone, Liboria: «L'Archivio privato gentilizio Papé di Valdina», Archivio storico messinese, vol. 79, 1999 , p. 7. 
hay remedio, hay que obedecer a tu padre». Andrea, después de la profesión dirá a la testigo: «A pesar de su despecho ha profesado, y ha cumplido con todo lo que yo quería, y era tan necesario para la conveniencia de mi casa» ${ }^{34}$.

Sola y sin apoyo, por temor de las amenazas violentas, primero «fue forzada a entrar en el noviciado» ${ }^{35}$, después a hacer la profesión y, en el mismo año, con las mismas amenazas a suscribir la renuncia no solo a los bienes paternos, vinculados por el fideicomiso, sino también a los bienes libres maternos, igualmente de considerable entidad. Señalamos, de paso, el alto valor simbólico de la elección del nombre monástico que se asume para marcar la separación de la familia de origen y del ambiente propio; Anna en cambio mantiene su nombre, añadiendo el de Maria Maddalena: «efectivamente el nombre de las profesadas a la fuerza señala su condición [...]; muchas buscaban conservar en la religión el nombre propio en el siglo» ${ }^{36}$.

Durante todos los años transcurridos en el convento aprovechaba toda ocasión para declarar públicamente frente a las otras hermanas y a los confesores que no era ni había sido nunca monja, porque había llegado a serlo por las amenazas de su padre; recurría a los superiores y se lo dijo también al arzobispo del momento, Jaime Palafox ${ }^{37}$, que en el trascurso de la visita al monasterio, intentó persuadirla para que ratificase la profesión. Muerto su padre el 3 de mayo de 1659, «caballero de mucho poder y rigidísimo» ${ }^{38}$, el mismo temor albergó hacia su hermano Giovanni, a quien le dijo no tener "vocación de espíritu» de permanecer en el convento y que, «con formas mucho más horribles» que las del padre, la amenazó con impedir que cualquiera la representara -«le haría cortar en pedazos si alguien se entrometía en semejante negocio ${ }^{39}$-en un eventual juicio de nulidad de la profesión. Algunos testigos declararon que en 1664 Anna había intentado encontrar un procurador que patrocinase la causa de nulidad, pero estos habían rehusado «entrometerse en los asuntos del hermano» por el perjuicio que ello les habría causado. «Todos temen servirme y me veré obligada a morir desesperada» ${ }^{40}$, había concluido Anna. También la solicitud a Giovanni Giangatto, que participaba en

34. Vol. 165, c. 182v. Cursiva mía.

35. Memoriale, vol. 164, cit., c. 6 r.

36. Medioli, Francesca: «Monacazioni forzate: donne ribelli al proprio destino», Clio. Rivista trimestrale di Studi storici, A. XXX, n. 3, 1994, p. 438.

37. Jaime de Palafox y Cardona fue arzobispo de Palermo desde 1677 hasta 1684. Su sucesor desde 1686 hasta 1702 fue Ferdinando Bazán y Manríquez.

38. Restitutiones Capitula et Jura, cit., vol. 164, c. 56v.

39. Íbidem, c. $54 \mathrm{v}$.

40. El testigo es Antonino Aguglia, de la Congregación de San Felipe Neri, íbidem, c. $29 \mathrm{v}$. Él cuenta a dos hermanos el episodio y estos le dicen que ha hecho bien, porque habían oído al príncipe gritar a su hermana «que se estuviese quieta, de lo contrario, si hubiese cogido procurador u otra cosa, la hubiera matado bajo un palo» Vol. 164, c. 30r. 
la causa de nulidad de sor Maria Luisa Ciambri, una hermana amiga de Anna, recibió el mismo rechazo: el abogado había rehusado asumir su procuración «sin una licencia con letras mayúsculas» del hermano ${ }^{41}$. El derecho canónico retoma la incapacidad del derecho romano que restringe la esfera jurídica de las mujeres ${ }^{42}$.

Anna «ha sido y es una mujer imbécil, temerosa y pusilánime» ${ }^{43}$, no puede, por tanto, a causa de la infirmitas sexus, incoar un juicio sin la autorización del cabeza de familia que, en su caso, no habría dado nunca su consentimiento. Y de hecho, solo después de la muerte del hermano, en 1692, Anna encontrará a quien la represente en la causa en la que pedía, de acuerdo con los cánones del concilio de Trento, de las leyes canónicas y de las bulas pontificias, «la nulidad de su nula profesión forzadamente hecha per vim et metum» ${ }^{44}$, y también la restitución de los bienes a los que había sido obligada a renunciar. Se nota el extraordinario énfasis de la frase: pide anular una profesión que ya es nula en la sustancia por haber sido exhortada, pronunciada por la violencia y el miedo ejercidos sobre ella.

\section{EL HERMANO GIOVANNI}

De los testimonios de los parientes emergen claramente las motivaciones de la familia Valdina ${ }^{45}$, ascendida con Pietro al principado en 1642 y radicada en territorio mesinés. Aquí la producción de la morera para la cría de los gusanos y la recaudación de los impuestos sobre la exportación de la seda están en poder de una élite - de la cual los Valdina forman parte- no solo local, sino sobre todo genovesa, que la comercializa en los mercados internacionales ${ }^{46}$. Desde el Val Demone -la «Sicilia del árbol», tan diferente de la del grano ${ }^{47}$ - ellos promueven la

41. Lo testimonia Carlo Rao, sirviente del sacerdote y tío de Maria Luisa Ciambri, íbidem, c. $33 \mathrm{v}$.

42. Leclerq, Henri: «Femme» en Dictionnaire d'archéologie chrétienne et de liturgie, vol. V, París, 1922, col. 1300 y ss.; Bride, André: «Femme», en Catholicisme, vol. IV, París, 1956, col. 1174 y ss. Dalla Torre, Giuseppe: «Imbecillitas sexus e confessio in judicio dei coniugi nelle valutazioni della canonistica classica», Archivio giuridico, 1983, vol. CCIII, fasc. 1-2-3, pp. 31-52.

43. Restitutiones Capitula et Jura, vol. 164, cit., c. 56r.

44. Memoriale, vol. 164 , cit., c. $1 \mathrm{v}$.

45. San Martino De Spucches, Francesco: Storia dei feudi e dei titoli nobiliari di Sicilia. Vol. VIII, Palermo, 1933, pp. 180-185.

46. Laudani, Simona: La Sicilia della seta. Economia, società, política. Roma, Donzelli, 1996, p. 56. Los herederos Valdina mantienen, aún en 1697, la «gabella del primo carlino» sobre la exportación de la seda por 1.400 onzas (3500 escudos), íbidem, p. 188.

47. Fazio, Ida: La politica del grano. Annona e controllo del territorio in Sicilia nel Settecento. Milán, Franco Angeli, 1993. 
escalada en las filas de la nobleza siciliana y ocupan cargos importantes en Palermo: Pietro, desde 1623 marqués de la Rocca y desde 1642 príncipe de Valdina, se había casado con Antonia Del Bosco y Velázquez, hija del duque de Misilmeri. Su cursus honorum incluía los cargos de diputado del reino (en 1621, 1624 y 1639), pretor de la ciudad de Palermo (en 1636-37 y en 1639-40), después notario mayor de la Regia Gran Corte, cargo adquirido para sí y sus descendientes. Había participado en la defensa de la ciudad en el curso de la revuelta capitaneada por Giuseppe Alessi en $1647^{48}$. A su muerte en 1652, su hijo Andrea había heredado los títulos y los bienes, se había casado con la genovesa Paola Vignolo y Papè, descendiente de la clase mercantil (y los Valdina mantendrán fuertes lazos con los genoveses), de quien tendrá nueve hijos, tres varones (Giovanni, Carlo, Vincenzo) y seis mujeres (Antonia, Laura, Caterina, Felice, Giovanna y Anna). No igualará a su padre en los cargos públicos ni en los títulos honoríficos, pero será caballero de Calatrava, gobernador de la Compañía de la Caridad y presidente de la Archicofradía para la redención de los cautivos en 1653; muere en Palermo en 1659. $\mathrm{Al}$ año siguiente el primogénito Giovanni se inviste con los títulos y hereda los bienes feudales y alodiales; como el abuelo, ocupa los cargos de notario mayor de la Regia Gran Corte en 1663 y de presidente de la Archicofradía para la redención de los cautivos en 1665. Giovanni, marqués de la Rocca y príncipe de Valdina, es un aristócrata hábil en los negocios y en la administración de sus posesiones, con una marcada vocación por el comercio y la inversión financiera. Rocca y Valdina son dos «estados feudales», dedicados a la cría de gusanos y a la manufactura de la seda, cuya cercanía a la costa y a la ciudad del estrecho facilita la exportación. La familia ha comprado desde 1635 la gabella di un tari por cada libra de seda que salga desde las calandrias de los dos territorios a la que, en 1638, ha añadido la del carlino sobre la exportación de la seda. Giovanni difiere en muchos aspectos de la nobleza de la Sicilia occidental -que quizás lo considera un arribista y un provinciano- y esto le ayuda a hacerle madurar posiciones antiespañolas. Sus cartas contienen juicios severos sobre Palermo, sus habitantes, la corte virreinal, los nobles; describe una Sicilia sumida en el caos, presa de la anarquía y de la degradación moral e institucional; acusa de avaricia y de corrupción al virrey

48. Siciliano, Anna: «Sulla rivolta di Palermo del 1647», Archivio storico siciliano, 1939, pp. 183-303; Königsberger, Helmut G.: «The revolt of Palermo in 1647», The Historical Journal, n. 8, 1946, pp. 129-144; Musi, Aurelio: «La rivolta antispagnola a Napoli e in Sicilia», en AA.VV., Storia della società italiana, vol. XI, Milán, Teti, 1989, pp. 317-358; Ribot García, Luis: «Las revueltas de Nápoles y Sicilia», Cuadernos de Historia Moderna, n. 11, 1991, pp. 121-130; Giarrizzo, Giuseppe: «La Sicilia dal Cinquecento all'Unità», en Vincenzo D'Alessandro y Giuseppe Giarrizzo: La Sicilia dal Vespro all'Unità d'Italia. Turín, UTET, 1989, p. 321 ss.; Palermo, Daniele: Sicilia 1647: voci, esempi, modelli di rivolta. Palermo, Associazione Mediterranea, 2009. 
duque de Uceda ${ }^{49}$. La revuelta antiespañola de Mesina de 1674-78 la causan una serie de factores, entre ellos la incapacidad del gobierno para armonizar los intereses de las dos partes de la isla, «de las dos Sicilias distintas» ${ }^{50}$ : la aristocrática y cerealista instalada en Palermo, por un lado, y, por el otro, la mercantil y casi burguesa, próspera gracias a la sericultura, representada por Mesina. Los Valdina y los Ventimiglia, emparentados entre sí (así mejor), habrían urdido oscuras maniobras contra España ${ }^{51}$ y Giovanni habría organizado, junto con los Diana de Cefalà y los Montaperto de Raffadali, un «partido francés». Su participación en la conjura antiespañola de Mesina provoca que el 30 de abril de 1676, «en Palermo se echara bando contra el príncipe de Valdina ${ }^{52}$, el cual se ve obligado a darse a la fuga para evitar el arresto y, desbordado por los acontecimientos políticos ligados a la revuelta, a permanecer en el exilio desde 1676 al 1688, primero en Francia y después en Génova ${ }^{53}$.

Solo en 1702 se concede el indulto a los exiliados a quienes se les había confiscado los bienes; Giovanni consigue volver a Sicilia, después de doce años de exilio; un retorno amargado por la acusación de robo en el ejercicio del oficio de notario mayor de la Regia Gran Corte que le costará cinco meses de arresto domiciliario. «Creía que había llegado al punto de una quietud necesaria a mi edad avanzada», pero «el ruinoso y despreciable estilo siciliano» lo golpea de nuevo, haciéndole sentir rechazado por su país. No extraña el deseo de Giovanni de abandonar Sicilia junto a su patrimonio. Para llevar a cabo este propósito reordena las cuentas y la administración de las propiedades mesinesas, decide qué llevarse consigo a Roma, cuando las galeras papales pasasen por Mesina por la feria de agosto. Muere, sin embargo, antes de realizar estos propósitos.

49. Juan Francisco Pacheco Téllez-Girón, duque de Uceda (Madrid 1649 - Vienna 1718), fue virrey de Sicilia desde 1687 hasta 1696, cuando dejó Sicilia por el cargo de embajador de España en Roma.

50. Ribot García, Luis: La revuelta antiespañola de Mesina. Valladolid, Universidad de Valladolid, 1982, p. 239.

51. Trasselli, Carmelo: «Messina 1674», en AA. VV.: La rivolta di Messina (1674-1678) e il mondo mediterraneo nella seconda metà del Seicento. Actas del Congreso, Messina, 1975; Villari, Rosario: «La rivolta di Messina e la crisi del Seicento», en Saverio Di Bella (ed.): La rivolta di Messina (1674-1678) e il mondo mediterraneo nella seconda metà del Seicento. Cosenza, Luigi Pellegrini Editore, 2001, pp. 29-42. Ventimiglia y Valdina serán procesados a su regreso; Ribot García, Luis: La Monarquia de España y la guerra de Mesina (1674-1678). Madrid, Editorial ACTAS, 2002.

52. Auria, Vincenzo: «Memorie varie di Sicilia nel tempo della ribellione di Messina», en Gioacchino Di Marzo (ed.): Biblioteca Storica e Letteraria di Sicilia. Vol. VI, Palermo, 1870 (rist. anastatica Bolonia, Forni, 1973), p. 21.

53. Chiaramonte, Socrate: «La rivoluzione e la guerra messinese del 1674-1678», Archivio Storico Siciliano, 1899, pp. 547-548; Arenaprimo, Giuseppe: Gli esuli messinesi dal 1636 al 1674. Mesina, 1900. 
No podemos comprender este personaje solo a la luz de su obstinación por mantener en el claustro a sus hermanas. De su correspondencia emergen el interés por el arte y el teatro, la generosidad en las relaciones de amistad; los regalos a su hermano Carlo cuando en 1661 va «fuera para recorrer el mundo», o «a cuenta de la legítima» cuando en 1669 se casa con Caterina Mendoza y Sandoval, los regalos de valor al virrey y a Ugo Papé; el encargo de obras de arte a Agostino Scilla y a Alonso Rodríguez ${ }^{54}$. Giovanni posee un Cristo con la cruz de Caravaggio, címbalos y guitarras, violas y una espineta veneciana, mapas geográficos, mapamundis y «globos celestes», brújulas, compases, reglas, recibe "periódicos semanales» y gacetas que lo informan de lo que sucede fuera de Sicilia. Entre sus amigos de más confianza está Marcello Cremona.

Su testamento ${ }^{55}$ resuelve el problema de la falta de herederos directos mediante la fundación en Roma de la riquísima prelatura Valdina, con el objetivo de representar a Sicilia ante la Santa Sede y nombra como sus fideicomisarios y ejecutores testamentarios al abad Giovanni Bernardino Noceti y a don Carlo de Gregorio. El primero, mesinés, prelado doméstico de la Santa Sede, durante más de treinta años arcediano y canónigo de la iglesia Metropolitana de Mesina, será designado por Giovanni primer titular de la prelatura Valdina, además de administrador de su ingente patrimonio. El príncipe no tiene tiempo de escribir los Capítulos de la nueva prelatura y será el propio Noceti quien los formule en 1724 y los publique en 1728 -cómodamente, cuarenta años después de la redacción del testamento-, previendo el traslado a Roma de todos los bienes. Giovanni muere el 24 de mayo de 1692 y la sucesión desencadena un durísimo conflicto judicial en el que también participa Anna cuando, vuelta al estado laico, pretende la restitución de los bienes paternos y maternos.

\section{LOS USURPADORES DE LA HERENCIA DEL HERMANO}

Bernardino Noceti, como heredero universal de Giovanni, es el principal antagonista de Anna. El 7 de noviembre de 1692, cinco meses después de la muerte del príncipe, él responde a una carta de la monja: con tono suplicante lamenta cuánto le habían «agujereado el alma sus punzantes y resentidas palabras», sin duda

54. Agostino Scilla (Mesina 1629-Roma 1700), pintor, científico y numismático, tras el fracaso de la revuelta antiespañola, se exilió primero en Turín y después en Roma; Alonso Rodríguez (Mesina 1578-1648) trabajó en Venecia, Nápoles, Roma, finalmente en Mesina, influenciado primero por Caravaggio, después por pintores nórdicos. Ambos gozaron de una cierta fama como pintores.

55. Testamento e codicillo di D. Giovanni Valdina, dati a conservare chiusi e sigillati, cioè il testamento al notaro Vincenzo Costanzo della Terra della Rocca a' 11 di Novembre 1688 [...] $e$ in Palermo al notaro Leonardo di Miceli a 4 de Decembre 1688. Palermo, 1694. 
inspiradas por los manejos de personas que le «odian y le aborrecen», una penosa mortificación que no cree merecer. Y, al fin y al cabo, afirmaba haber servido a la casa Valdina durante treinta y cuatro años «con afecto desinteresadísimo»; su querido y añorado amo quiso «ejercer hacia mí -escribe- una generosa caridad y sabe Dios que [...] positivamente me opuse a cuanto él quiso disponer a mi favor», hasta que capituló frente a la firmeza de su benefactor. Anna le pide la cuenta y razón de la administración de los bienes de su hermano y especialmente de las sumas destinadas a obras de caridad, obteniendo un rechazo dilatorio, entre hipócritas expresiones de respeto. Noceti miente descaradamente cuando escribe: «ningún detrimento me aportaría el cambio de su estado, más bien no poca quietud de ánimo y tranquilidad de conciencia, que soy un hombre muy estoico y despegado de toda ambición e interés y al papado, no solo a una prelatura, renunciaría voluntarísimamente, cuando se pusiese en un mínimo riesgo mi fama». Los censos que Anna quiere dar en limosnas deben ir, según la voluntad de Giovanni, a personas miserables «de las cuales aquí [en las tierras de la Rocca] es copioso el número»; le ha mandado ya 30 onzas, tomadas de las 200 destinadas a limosnas y está realmente estupefacto (ammiratissimo) de que ella no se sienta satisfecha y quiera más ${ }^{56}$. En realidad Noceti no ha informado ni siquiera al arzobispo de Mesina ${ }^{57}$ de los legados testamentarios destinados a las obras pías, una obligación desatendida que podría costarle mil onzas de pena, si el prelado decide proceder judicialmente contra él ${ }^{58}$. Anna adjunta esta carta como prueba del interés del abad por no entregar las cuentas de la herencia, de la falta de ejecución de las obras de caridad dispuestas por el difunto, de que su hermano conoce su voluntad de dejar el hábito, de la intención de excluirla del control sobre las acciones hechas en calidad de fideicomisario. A la luz del contencioso en curso la carta de Noceti parece falsa, meliflua, dilatoria.

Una Giustificazione del abad, incluida en las actas del proceso, contradice la reconstrucción de la «monja válidamente profesada» y nos ofrece una versión especularmente opuesta a la de Anna, que se había definido como «monja nulliter profesada»: defiende al príncipe Pietro, presente en la ceremonia de profesión, quien nunca habría consentido que usasen la violencia contra su nieta y quien habría ciertamente hecho valer su autoridad para impedir tal escándalo y a Martín de León ${ }^{59}$, prelado de admirable celo pastoral, presente también en la ceremonia,

56. La carta, copiada el 26 de octubre de 1793, para ser adjuntada a los actos está en el vol. 166, cc. 36r.-39r.

57. Francisco Álvarez de Quiñones fue obispo de Mesina desde 1686 hasta 1698.

58. Scritture collectae del 5 de julio de 1694, vol. 166, cc. 95v.-96r.

59. El español Martín de León Cárdenas o Cardines (1585-1655), después de haber sido durante casi veinte años obispo de Pozzuoli, fue nombrado arzobispo de Palermo en 1650 y al año siguiente fue presidente del reino. Murió en Palermo antes de obtener la púrpura cardenalicia. 
quien no habría permitido «una acción tan escandalosa y contraria a la ley de Dios como es la de forzar los padres a sus hijas a hacerse monjas a la fuerza» ${ }^{60}$. Si Anna hubiese sido realmente reacia, habría podido escribir al prelado o advertir al confesor o confiárselo a la abadesa, obligada a explorar su voluntad. Su hermano Giovanni sentía en sus encuentros una «particular ternura y confianza» hacia ella y, durante el exilio, le escribió cartas en las que lamentaba la lejanía de sus hermanas ( $\mathrm{y}$ de Anna en particular), quien habría podido asistirlo durante su «enfermedad de podagra» ${ }^{61}$. En efecto, las numerosas cartas de Anna, contenidas en el expediente judicial, escritas al hermano en el exilio entre 1676 y 1686, están llenas de expresiones de afecto («hermano de mi corazón», «os amo y quiero con entrañable amor») y preocupaciones por la salud del destinatario («por los cansancios de vuestra persona y los sufrimientos infinitos que se han pasado aquí en esta patria ingrata y traidora»); una carta del 18 de julio de 1685 anuncia la muerte de su hermana Giovanna. Sin embargo, estas cartas contienen sobre todo la frustración de la remitente por la rigidez de Giovanni y reproches por su desinterés hacia su infeliz condición ${ }^{62}$. Los hermanos Valdina no habían crecido juntos, ninguna parenté pratique había creado sentimientos y dado eficacia a los lazos de parentesco más allá de las raíces biológicas ${ }^{63}$ más que en los años lejanos de la primera infancia; Anna se describe sola, abandonada y necesitada de todo. Según Noceti, la imagen de un hermano amoroso, no de un déspota insensible, contradice la reconstrucción de la mujer; igualmente Vittoria Valdina y del Bosco y la hermana Giovanna Lucchese y Valdina no son testimonios fidedignos, porque litigaron con Andrea y Giovanni por cuestiones hereditarias; así como todas las demás, «personas familiares y apasionadas, padecen respectivamente muchas objeciones» ${ }^{64}$, no pueden ser consideradas testimonios objetivos y, de hecho, ocultan la verdad: Anna había querido hacerse monja.

En la apertura del proceso arzobispal, el 27 de noviembre de 1693, con gran rapidez la abadesa del monasterio delle Stimmate, Giuseppa Margherita Lucchese y Filangieri, a través de su procurador y consejero, Pietro Filangieri y Notarbartolo, príncipe de Santa Flavia, se opone a la aceptación de la instancia de Anna en ausencia de la disposición apostólica, dado que han transcurrido nueve quinquenios desde la profesión. El 23 de marzo de 1694, la corte se pronuncia a favor

60. Giustificazione del abad Bernardino Noceti, sin fecha (1698?), vol. 165, c. 294v.

61. Vol. 165 , c. 295 r.

62. La carta está en el vol. 165 , c. 530 r.

63. Lett, Didier: «Prefazione» a Benedetta Borello: Il posto di ciascuno. Fratelli, sorelle e fratellanze (XVI-XIX secolo). Roma, Viella, 2016, p. 13.

64. Laura del Bosco Castelli y Leonora del Bosco Bologna, princesas de Belvedere, son parientes y «en estrecha correspondencia»; sor Croce Maria Frangipane, Francesco Chichicciola, hermano Eustachio de Palermo, etc., vol. 165, c. 295v. 
de la abadesa y Anna apela al Tribunal del Consistorio ${ }^{65}$ que en cambio decide a su favor, revoca aquella sentencia y permite así al tribunal arzobispal que acoja a los testigos. Contra la «malvada intención» de Anna la abadesa apela al Tribunal de la Monarquía, pero a causa de la falta de nombramiento de un curial por parte del monasterio, y por tanto por un vicio de forma, debe ceder. El 11 de agosto de 1695, ya cerca de la expiración del trienio de su mandato, «por descarga de su conciencia», porque no han sido acogidas sus peticiones en la sede local, la abadesa escribe al Papa sobre la

«gravísima y sumamente escandalosa novedad en este mi monasterio con circunstancias no vistas en otros casos parecidos. La detestable facilidad con que suelen en este reino de Sicilia admitirse las instancias sobre nulidad de profesiones de regulares de uno y otro sexo no será creo desconocida por Vuestra Santidad. Pero el mayor de tales desórdenes en esto es el de dar acceso a quien espera tales recursos incluso sin dispensa de la Santa Sede Apostólica por el transcurso del quinquenio con ausencia de reclamación $»^{66}$.

Sor Anna Maddalena Valdina, hoy sexagenaria, sin haber nunca reclamado en los cuarenta y cuatro años de profesión, desde hace un año se deja seducir por «sugerencias perversas» de intentar el juicio de nulidad de sus votos para volver a ser seglar y quien debería oponerse a tal «abominable intento» no hace su deber. Solo desde hace un año, según la abadesa, y bajo instigaciones externas de un oculto e interesado promotor, Anna habría comenzado a lamentar su condición de monja a la fuerza y ciertamente la edad avanzada de la mujer convierte su elección en oscura y de escandaloso ejemplo para las más jóvenes. El juez de aquella corte arzobispal hoy es ministro regio, prosigue la abadesa, demostrando de cuánto provecho podría ser la conducción de las causas en el fuero eclesiástico, dejando suponer una complaciente conducción del proceso.

Once años atrás salió del convento otra religiosa, amiga de esta, gracias a un primo con quien contrajo matrimonio, «pero hace años murió por un aborto. Aquella realmente siempre había dado signos de aversión hacia el estado religioso y estaba en edad juvenil, sin embargo el arzobispo Palafox le impidió el intento» ${ }^{67}$. En efecto, Francesca Lucchesi Palli y Campo (1627-1683), que había profesado forzada por su hermano, finalmente única heredera de la fortuna de la familia,

65. Instituido en 1569 por Felipe II en sustitución del antiguo Tribunal de la Regia Conciencia, con tres jueces con cargos bienales y un presidente, «instruía, en apelación y revisión, las causas de cualquier corte e incluso algunas causas eclesiásticas tramitadas por el Tribunal de la Regia Monarquía». Oddo, Francesco D.: Dizionario di antiche istituzioni siciliane, Palermo, Flaccovio, 1983, p. 146.

66. Supplica al Papa, Palermo, 11 de agosto de 1695, vol. 166, c. 128v.

67. Vol. 166, c. 129 r. 
con la ayuda de su primo Salvador consiguió obtener la nulidad de la profesión, salir del convento, heredar el principado de Campofranco y casarse con el primo, a pesar de que la excomunión había sido fulminada contra la pareja ${ }^{68}$. El caso de Anna es diferente -sostiene la abadesa- $y$, «si no se cierra esta puerta, otras monjas intentarán hacer el mismo camino sobre vestigios licenciosos ${ }^{69}$.

La posición de la abadesa coincide con la de Marcello Cremona, sucesor de su tío Bernardino Noceti en la prelatura -con el tiempo refrendario del Tribunal de las dos Signaturas Apostólicas (la de gracia y la de justicia), entre los más importantes dicasterios de la curia romana- el cual recapitula así los hechos: a su muerte Giovanni Valdina instituye como heredera universal a su propia alma y con dos codicilos destina sus bienes a obras pías, la primera de las cuales es una prelatura perpetua y sacerdotal en la corte papal que lleva su nombre y su escudo de armas, con renta anual y dote. En octubre de 1693, sor Anna,

«seducida por depravados consejos, un año y medio después de la muerte de Giovanni, contra cualquier principio de razón introdujo la instancia para que se declarase nula su profesión, después de haber perseverado en ella por espacio de 43 años aproximadamente, es decir, desde 1651, sin haber nunca hecho la mínima reclamación, incluso haber administrado todos los oficios de la religión, excepto el de abadesa, al que muchos años atrás había aspirado pero no lo consiguió y haber aceptado (un año y meses después de la muerte del hermano) los cargos de ecónoma de dicho monasterio [...] cuando intentó el vano e injustísimo juicio de anulación de sus votos» ${ }^{70}$,

llamando en juicio al monasterio y al ejecutor testamentario del hermano. Estos últimos piden que sea aplicada la norma «denegationis audientiae ob lapsum quinquennii absque reclamatione» y que no se proceda ad ulteriora. Cremona tiene algo de razón: en efecto sor Anna ha dirigido el procedimiento con un Memoriale a la competente corte arzobispal y no a través de la súplica al Papa; esta acepta -imprudentemente, según Cremona- la admisión de los testigos citados por la

68. Testa, Giuseppe: Suor Francesca, principessa e monaca nel monastero della Badia nuova di Palermo. Palermo, Flaccovio, 1976. En el mismo monasterio que Anna en «1604, a 23 de octubre entró [a las Llagas] Giovanna Settimo, hija del marqués de Giarratana, a 30 de dicho [octubre] tomó el hábito y se puso nombre sor Clara Maria. La susodicha salió del monasterio». Cfr. ASPa, Corporazioni religiose soppresse, Monastero delle Stimmate, vol. 70, cit. en Salamone, «L'Archivio privato gentilizio Papé di Valdina», cit., p. 7.

69. Vol. 166, c. 129v. Entre nuestra documentación aparecen actos relativos a la causa de nulidad del trapanés Tommaso Ciambra, ingresado en el convento en 1613 y una carta del arzobispo de Palermo al rey, alcanzado por dos súplicas sobre la causa de nulidad de Francesca de Spucches, desde Madrid el 29 de enero de 1658. Vol. 166, Scritture diverse, passim. 70.Vol. 165 , c. 432 r. 
demandante, sin haber sido requerida por la Sacra Congregación de los obispos y de los regulares a quien el Papa debería haber remitido la cuestión.

En abril de 1695 la abadesa se dirige, como sabemos, al Papa, el cual remite su recurso a la Sacra Congregación de los obispos y de los regulares que, el 16 de septiembre de 1695, ordena al arzobispo palermitano suspender la causa. Este se lo comunica a la hermana, pero no transmite los actos y la causa es avocada por el Tribunal de la Regia Monarquía que, el 6 de julio de 1699, decide a favor de la mujer, declarando nula su profesión. La corte arzobispal, que habría debido apelar de oficio, no lo hace y, transcurridos los plazos legales ( $i$ fatali), la sentencia es firme. Aunque la abadesa y el protector del monasterio, dejando transcurrir los plazos sin haber reunido el capítulo y pedido a las monjas que votaran, contribuyen involuntariamente a este resultado.

Los «consejos depravados» a la monja y los impedimentos al cumplimiento de las formalidades se deben -escribe Cremona- a la prepotencia de don Ugo Papé, duque de Giampilieri, protonotario del reino de Sicilia, «tío de la monja y su donatario en todas la razones que le pueden competer, supuesta la pretendida nulidad de la profesión, sobre los bienes heredados del príncipe, con la extravagantísima cláusula de poder proseguir el juicio de dicha nulidad incluso después de la muerte de la donante ${ }^{71}$. Aquí aparece el consejero de Anna, el que sabiamente inspira las iniciativas legales, que influye en los jueces de la corte arzobispal y del Tribunal de la Regia Monarquía, que actúa por puro interés personal, habiendo sido nombrado donatario de todos los bienes que la mujer reivindica, una vez obtenido el estado laico. Y, a pesar de la oposición primero de Noceti y después de Cremona, se ha procedido a la ejecución de la sentencia y, veinticinco días después de su promulgación, el 1 de agosto de 1699, «salía la monja del sagrado claustro», a la edad de sesenta y cinco años, después de cuarenta y nueve años de profesión, «con universal escándalo y perniciosísimo ejemplo» ${ }^{72}$. Con alivio y miedo de Anna -imagino-, quien, vuelta al siglo, hace inmediatamente la instancia de restitución de la herencia Valdina, haciendo poner bajo secuestro los bienes existentes en Sicilia y fuera del reino, asignados por el hermano en dote a la prelatura. En este punto Marcello Cremona pide al Papa que la causa sea avocada a la Sacra Congregación romana y que la monja sea obligada a volver ad claustra, como en efecto, el 12 de junio de 1700, la Sacra Congregación ordena al arzobispo que disponga sub poenis apostasiae $^{73}$. Un duro golpe para la monja recién secularizada.

71. Vol. 165 , c. $432 \mathrm{v}$.

72. Vol. 165 , c. 433 r.

73. Vol. 165, c. 434r. «Anna Valdina redeat ad claustra, sub pœnis Apostasiae ad formam Sacrii Concilii Tridentini». 


\section{EL ATASCO JURISDICCIONAL}

En 1695 Anna toma dos decisiones complementarias e igualmente decisivas: renuncia a cualquier pretensión de restitución de su dote monástica, dejada a disposición del monasterio delle Stimmate, neutralizando de ese modo un peligroso actor judicial y, después de haber revocado las donaciones anteriores a favor del primo Giovanni Bautista Valdina, dona todos sus bienes a Ugo Papé, duque de Giampilieri, protonotario del reino ${ }^{74}$. Su madre Paola era hija de Agostino Vignolo y de Caterina Papé y Ugo era sobrino de Caterina, y por tanto tío de Anna. Ella pone pues su causa, no solo bajo la protección de un personaje muy influyente y con alianzas ramificadas, a partir de la del arzobispo Bazán, con el virrey y su corte, sino que también pone las condiciones para que ésta se convierta en un caso político, basado en la defensa de los privilegios del reino de Sicilia contra las injerencias romanas. El conflicto de competencia que se desarrolla en torno al proceso contrapone la curia arzobispal palermitana y el Tribunal de la Regia Monarquía a la Sacra Congregación de los obispos y de los regulares y a la curia romana; en última instancia, el rey de España al Papa.

La competencia de la Regia Monarquía se basa en la prerrogativa de los soberanos de Sicilia de ejercitar, además de la potestad in temporalibus, también la jurisdicción sobre los eclesiásticos a través de un tribunal presidido por un prelado de nombramiento real, en virtud de una tradición que hace derivar esa prerrogativa de un privilegio concedido en 1098 por Urbano II al conde normando Roger. Con este privilegio el rey de Sicilia, por el mérito de haber liberado la isla de los sarracenos, era considerado legado apostólico del Papa, su vicario. Desde entonces los reyes sicilianos, sucesores del primer Roger, pretendieron para sí la prerrogativa de haber «nacido legados». La Apostólica Legacía, por tanto, concentraba en la persona del rey la potestad espiritual y la temporal ${ }^{75} \mathrm{y}$ el Tribunal de la Regia Monarquía representaba el brazo judicial. El 3 de agosto de 1559, Felipe II disponía la institución del Tribunal del Consistorio de la Sacra Regia Conciencia, «una magistratura de apelación estable, con competencias definidas, [...] entregaba definitivamente los destinos de los jueces eclesiásticos a un magistrado secular» ${ }^{76}$. Las prerrogativas del Tribunal de la Monarquía se

74. Ugo Papé y Notarbartolo fue maestro notario y secretario de la Diputación del reino (1666-1701), diputado del reino (1684-1690); maestro portulano (1693-1701); tesorero general (1674-1675); gobernador de la Compagnia dei Bianchi (1677-1690); vicario general en Val di Noto en 1679, protonotario del reino (1693-1715). El oficio de protonotario pertenecerá a Papé hasta su abolición en 1819. San Martino De Spucches: Storia dei feudi, cit., vol. IV, pp. 66-67.

75. Fodale, Salvatore: L'Apostolica Legazia e altri studi su Stato e Chiesa. Mesina, Sikania, 1991.

76. Napoli, Maria Teresa: La Regia Monarchia di Sicilia. «Ponere falcem in alienam messem». Nápoles, Jovene, 2012, pp. 2, 216, 217. 
ampliaron en el tiempo, impidiendo el recurso a la curia romana para gran parte de las causas eclesiásticas; allí se apelaban las sentencias de los obispos y arzobispos en las causas civiles y penales, matrimoniales, etc.; allí se concedían las dispensas por impedimentos matrimoniales, allí se ratificaba el nombramiento de superiores y abades, allí se anulaban las investiduras religiosas ${ }^{77}$. Los obispos sicilianos protestaron numerosas veces, pero sobre todo fueron muchísimos los casos de conflicto entre Regia Monarquía, obispos, superiores de las órdenes religiosas, Santo Oficio, virreyes, Congregaciones romanas ${ }^{78}$. «El procedimiento por el cual las apelaciones al ordinario iban al rey o al virrey, es decir a un juez eclesiástico de nombramiento virreinal, flanqueado por la Gran Corte [...] servía para impedir la extracción de las causas a Roma, para abreviar el procedimiento de los procesos, para tutelar el orden público y el buen funcionamiento de la justicia» ${ }^{79}$.

A causa de tal maraña de jurisdicciones, la batalla judicial pronto se vuelve incandescente: habíamos visto a Anna recurrir al tribunal arzobispal, a Noceti acudir al de la Regia Monarquía que, el 23 de marzo de 1694, le da la razón; el 5 de julio de 1694, Anna obtiene del juez eclesiástico, con el voto del Tribunal del Consistorio y de la Sacra Regia Conciencia, la revocación de la sentencia arriba mencionada; el abad pide ser dispensado del juicio al ordinario obteniendo, el 8 de enero de 1700, una respuesta negativa y esto lo empuja a dirigirse a la Sacra Congregación de los obispos y de los regulares en la Santa Sede. Será esta última quien pedirá al arzobispo palermitano que, según las normas tridentinas, «en la causa de la nulidad de la profesión no se siguiese adelante [...] por haber transcurrido un quinquenio de la debida reclamación» ${ }^{80}$. Anna, al dirigirse al arzobispo, observa que «el quinquenio no había transcurrido nunca mientras vivió Giovanni por quien era continuamente atemorizada para no proponer aquella petición. [Además] los regnícolas no pueden litigar en tribunales fuera del reino». Las órdenes de la Congregación romana son por tanto contrarias a las Constituciones y a los Capítulos del reino «y son de ninguna fuerza y valor» ${ }^{81}$; en consecuencia, no se puede proceder en el sentido solicitado por la Santa Sede.

Anna envía también a la Congregación romana un Memoriale, en el que reconstruye su punto de vista sobre la cuestión, contradiciendo la versión de Noceti: la mujer lo acusa de haberse apropiado no solo de la opulentísima herencia del príncipe Giovanni, sino también de los créditos de la dote materna y de

77. Zito, Gaetano: «Sicilia», en Id. (ed.), Storia delle Chiese di Sicilia. Ciudad del Vaticano, Libreria Editrice Vaticana, 2009, pp. 60, 66.

78. Varios casos son reconstruidos en D’Avenia, Fabrizio: La Chiesa del re. Monarchia e Papato nella Sicilia spagnola (secc. XVI-XVII). Roma, Carocci, 2016.

79. Napoli: La Regia Monarchia di Sicilia, cit., p. 231.

80. Vol. 165 , cit., c. $375 \mathrm{v}$.

81. Íbidem. 
otras rentas que pertenecen a la solicitante, de haber hecho que la prelatura fuese conferida a su sobrino Marcello Cremona y de haber practicado «todas las dilaciones posibles» ${ }^{82}$ en la causa. Fallecido Giovanni, no por casualidad, el duque de Giampilieri, protonotario del reino y tío del difunto, y el duque de Uceda renunciaron a hacer de ejecutores testamentarios «por haber sido el testamento urdido en modo que toda la autoridad debía depender de Bernardino Noceti» ${ }^{83}$. Con toda claridad sobresale «la intención de Noceti, árbitro de esta herencia, de disipar las sustancias del testador sin haber llevado a cabo un mínimo de las obras pías dispuesta por el mismo». Al contrario, dos años después de la muerte del príncipe Giovanni, Noceti saca a relucir un codicilo con el cual, manipulando la voluntad del testador, pervierte la disposición testamentaria y deja mano libre al fideicomisario, que no deberá rendir cuentas a nadie por su administración ${ }^{84}$.

Anna se dirige por esto al virrey, duque de Uceda, para que ordene a Noceti rendir cuentas, tal y como lo había pedido a su vez al obispo Álvarez de Mesina y como el Tribunal del Consistorio y de la Regia Monarquía le obliga ahora a hacer. La solicitante pide que sea reconocida la falsedad del codicilo en cuestión y revocado el decreto del 12 de junio de 1700 que le ordena volver al convento ${ }^{85}$, permitiéndole de ese modo hacer valer sus derechos contra el usurpador de la herencia de su hermano.

\section{EL CORTE SALOMÓNICO: LA CONCORDIA}

El conflicto ha llegado ciertamente demasiado lejos, ha implicado a las más altas magistraturas del reino, se ha sumado a un pulso entre Palermo y Roma y ahora genera bochorno en Madrid. Algunos personajes, entre ellos el marqués de Analista ${ }^{86}$ trabajan para buscar un acuerdo entre los contendientes y se comienza a elucubrar sobre qué incluir en un eventual acuerdo (deudas, créditos, frutos, etc.). Anna envía también al rey un Memoriale en el que, después de una breve explicación sobre la causa de nulidad, llega al grano: el abad Noceti está disipando «una

82. Memoriale di Anna Valdina alla Sacra Congregazione dei Vescovi e dei Regolari, vol. 165 , c. 417 r.

83. Íbidem, vol. 165 , c. 415 r.

84. Memoriale di Anna Valdina, cit., vol. 165, c. 414r.

85. Íbidem, cc. 420r.-v.

86. Descendiente de una familia genovesa un Pietro Santoro fue juez pretoriano de Palermo en los años 1698-99, 1707-8, del Tribunal del Consistorio en 1703-4, de la Gran Corte en los años 1706-7, 1713-14-15, abogado fiscal del Tribunal del Real Patrimonio en 1720; aunque con el título de marqués de Analista fue condecorado su sucesor, Bernardo, en 1752. Mango di Casalgerardo, Antonino: Nobiliario di Sicilia. Palermo, Reber, 1912. El volumen se encuentra en línea: http://www.regione.sicilia.it/beniculturali/bibliotecacentrale/mango/santoro.htm 
de las más pingües herencias del reino y ha hecho transportar dinero en efectivo a Roma con las galeras pontificias que han estado en Mesina [...] sin haber cumplido ningún legado ni obra pía de las muchas dispuestas por el príncipe Giovanni en su testamento», contra el cual el arzobispo de Mesina ha presentado oposición. Pero además, la mujer evoca «el notable perjuicio [que] resultaría a la regia Monarquía de vuestra majestad y a los Capítulos del reino con la avocación de semejantes causas a la corte de Roma, cosa nunca vista en el reino» ${ }^{87}$.

Por su parte, monseñor Marcello Valdina (ya no Cremona por haber sido investido por el tío Bernardino Noceti como primer titular de la prelatura Valdina y por haber cumplido la obligación del testador de que el titular de la prelatura asumiese el nombre y las armas de su casa), ahora refrendario de Su Santidad, escribe al rey de Nápoles y, arrojándose a sus pies, expone «el agravio» del Tribunal de la Monarquía de Sicilia al anular la profesión y al hacer salir del convento a la «secularizada religiosa». El rey, informado de las evidentes razones del suplicante, había ordenado al cardenal Del Giudice ${ }^{88}$, virrey de Sicilia, «con repetidos reales despachos disponerse el suspenderse los pleitos y componerlos con una concordia entre las partes» y el cardenal-virrey había establecido que cada una de las partes en la causa nombrase compromisarios ${ }^{89}$. La decisión de compromiso, de la que se discute incluso en una sesión de la Real Audiencia de su majestad, no parece sin embargo agradecida por Marcello Valdina, que pide diplomáticamente poder dirigir todos los requerimientos a Roma, donde está «radicado» y que la causa sea sentenciada por la Santa Sede, «a quien privativamente y sin excepción ninguna, pertenecen semejantes causas», sin trastornar lo dispuesto por el noble testador al servicio de ambas majestades, la divina y la humana ${ }^{90}$.

El 12 de junio de 1700, el propio Marcello Valdina presenta a la Sacra Congregación una breve historia de la prelatura, a la cual le ha sido otorgada una asignación anual de 300 escudos de moneda romana, «cuya posesión ha sido admitida por la santidad de nuestro señor y por la marca plena de justicia», es decir, por la corte de la que él mismo es un refrendario. La reconstrucción es un acto de acusación de la parcialidad del tribunal arzobispal palermitano y aviva las llamas del conflicto con Roma. Acusa a la corte arzobispal de no haber reconocido el impedimento formal de los cinco años; de no haber cumplido la orden de la Sacra Congregación de los obispos y de los regulares de enviar a Roma todos los actos y de haber permitido, de ese modo, que la causa fuese avocada por el Tribunal de la Regia

87. Memorial de Anna al rey, sin fecha, vol. 165, c. 461r.

88. Se trata de Francesco del Giudice (Nápoles 1647- Roma 1725), presidente del reino en 1702 .

89. El monasterio nombra a Francesco Maria Cavallaro, a los donatarios de la monja Nicola Pensabene y a S. E. Vincenzo Ugo, presidente de la Gran Corte y ministro de las prendas.

90. Súplica sin fecha, vol. 166, cc. 239r.-240r. 
Monarquía que, el 6 de julio de 1699, había decidido a favor de la monja que la profesión declaretur nulla. Contra esta sentencia el fisco del tribunal arzobispal no había opuesto ninguna apelación, como era su deber de oficio. Todo esto, repite, «no se hizo por la prepotencia de don Ugo Papé, duque de Giampilieri, protonotario del reino de Sicilia, tío de la monja y su donatario» ${ }^{91}$. Y a pesar de que Marcello Valdina hubiese hecho apelación, se había igualmente procedido a la ejecución de la sentencia veinticinco días después de su promulgación y el 1 de agosto de 1699 la monja había salido del claustro. Inmediatamente después Anna había recurrido para obtener «todo el cuerpo de los bienes heredados», excluyendo las propias obras pías, con la pretensión de ser acreedora de ingentísimas sumas a título de restitución de los frutos de los bienes paternos y maternos. Y con ese objetivo había hecho secuestrar todos los bienes de la familia existentes en el reino de Sicilia y fuera del reino, asignados por el testador como dote de la prelatura. Por tanto, «el solicitante» pide que se avoque la causa a la Sacra Congregación y que se ordene al arzobispo que imponga a la monja la reasunción del hábito y la vuelta a la clausura, después de lo cual podrá recurrir, si quiere, a la Santa Sede sin la cual toda sentencia es notoriamente «nula, inválida e injusta».

El duque de Uceda, conde de Montalbán, se interpone como mediador entre las partes: conociendo la disputa sobre la herencia Valdina, la nulidad de los votos de Anna y la validez de la prelatura, los recursos de Marcello Valdina para que se ponga en discusión la jurisdicción de la Regia Monarquía, se pronuncia en estos términos perentorios: «Yo [h]e estimado procurar el ajuste de esta cuestión amigablemente siendo la piedra del escándalo la permanencia de la prelatura cuyo beneficio es personal para el que hoy la tiene y perpetuo [... y considera] malsonante que los vasallos del reino pongan en discurso y en competencia la Monarquía $»^{92}$. El virrey no puede ignorar que «en Roma aborrecen tanto la jurisdicción de la Monarquía» ${ }^{93}$; él no parece simpatizar con Cremona y debe defender las prerrogativas del reino de Sicilia.

La cuestión Valdina se ha transformado poco a poco en un abierto conflicto jurisdiccional entre la Santa Sede y los antiguos privilegios de la Monarquía siciliana, un asunto de estado: la Sacra Congregación de los obispos y de los regulares pide al arzobispo que imponga el hábito a Anna sub poenis apostasiae; desde Palermo se responde explicando el impedimento para cumplir con la misma. «No se puede seguir ese decreto en el reino [...] por la preeminencia que goza su majestad católica de haber nacido legado como rey de Sicilia desde el tiempo del señor conde Roger que la recuperó de los sarracenos por quienes había sido

91. Carta de Roma, 12 de junio de 1700 , vol. 166 c. 248 r.

92. Carta del duque de Uceda del 7 de enero de 1701, vol. 166, c. 251v.

93. Vol. 166, c. 258 r. 
tiránicamente ocupada durante muchos siglos». Esto hace que las causas espirituales del reino no puedan ser avocadas por la corte romana, según la decisión unánime del Parlamento general, en el que participa también el brazo eclesiástico. Estas pasan del tribunal arzobispal al Tribunal de la Regia Monarquía -es decir, al juez eclesiástico nombrado por el virrey como vicario de su majestad- para ser decididos por el juez natural, por tanto, con el voto del Tribunal del Consistorio y Sacra Regia Conciencia y con el voto del Tribunal de la Corte criminal y causas delegadas y después con el voto del Tribunal de la Gran Corte civil y causas delegadas, y de nuevo con el voto del Consistorio, volviendo a la Regia Monarquía para la sentencia final. Este procedimiento codificado por el ordenamiento judicial siciliano «ha sido siempre observado, hay ejemplos de causas enviadas a Roma [...] por la autoridad de la Regia Monarquía, para no sufrir los regnícolas la vejación de no litigar con excesivos gastos fuera del reino, por lo que a menudo se habrían visto obligados a abandonar sus razones y a sucumbir a los otros poderes». Y tal preeminencia regia ha sido durante muchos siglos pacíficamente disfrutada y no puede abandonarse sin prejuicio de los vasallos ${ }^{94}$.

A la pretensión del prelado Valdina de que no se pueda proceder lasso quinquennio, se responde que él no tiene $j u s$ alguno sobre una causa religiosa, que el quinquenio no trascurre desde la profesión, si es obtenida per vim et metum, sino desde el día en que cesa el metum. Así se ha hecho en el caso de doña Francesca Lucchese y Campo que, obtenida la nulidad de la profesión, logró después de la Santa Sede la dispensa de matrimonio con un primo de segundo grado, a pesar de la oposición de Giacomo Fardella, el posesor de los bienes a los que la monja había sido obligada a renunciar. Se ha hecho por Anna Valdina lo mismo que se hizo por Francesca Lucchese. En definitiva, el prelado no puede ser admitido a comparecer en la causa de nulidad de la profesión por no perjudicar el buen jus de la supuesta monja y la preeminencia de la sacra majestad católica en el reino.

Mientras el primo Francisco Valdina se arroga el título de príncipe apoyándose en una sentencia de la Regia Gran Corte, como pariente más próximo en grado al difunto Giovanni, el virrey Uceda trabaja por una mediación razonable: escribe desde Roma el 10 de marzo de 1702 cuáles deben ser los puntos del acuerdo $^{95}$, sobre los que la transacción final asignará a Papé todos los bienes

94. Vol. 166, c. $627 \mathrm{v}$.

95. «1. La causa de la transacción debe ser por haber ambas parte conocido los grandes gastos y molestias que comporta el litigar y que, amigos communibus intervenientibus, han determinado venir al presente ajuste. 2. El cargo de maestro notario cum bonoribus, lucris et hemolumentis et pro ut spectat ad hereditatem predictam no debe entrar en la transacción o el señor duque se ne prende i crediti. 3. La herencia no debe ser molestada por terceros que certifican los créditos, 4. Lo mismo debe suceder con los bienes extra Regnum». Difficoltà della minuta inviata a Mons. Noceti, vol. 165, c. 705r. 
sicilianos y el título de príncipe de Valdina y a la prelatura los de fuera del reino: una victoria dividida a medias entre ambos contendientes, pero el final de un contencioso que no habría podido encontrar otra solución antes de la abolición de la Legacía Apostólica en 1871. En 1706, «los procuradores electos, por orden de su majestad, para atajar todos las disputas entre Giuseppe Papé y el reverendo Giovanni Bernardino Noceti, fideicomisario de la herencia del difunto Giovanni Valdina» ${ }^{96}$, asignan a Giuseppe el título de príncipe de Valdina; nace así la casa Papé-Valdina.

\section{LIBERTAD FEMENINA EN EL SEISCIENTOS}

Anne Jacobson Schutte se pregunta si de las peticiones de nulidad de la profesión monástica y de los testimonios emergen «algunos rayos de luz sobre los peticionarios -especialmente sobre las mujeres peticionarias- desarrollando un sentido de sí mismos. ¿Qué revela la declaración del testigo sobre los sentimientos más profundos [inner feeling] de los peticionarios? [...] Normalmente los peticionarios permanecen en las sombras» ${ }^{97}$. Los tribunales eclesiásticos centran su acción sobre el conflicto entre legítima libre elección e ilegítima constricción, pero «pocas veces formulan sus afirmaciones en términos de libertad» ${ }^{98}$. No así las mujeres profesadas a la fuerza, las cuales hacen referencia concreta al libre arbitrio de seguir la propia vocación, dentro y fuera del claustro.

En contraste con las determinaciones divinas, los impíos padres -escribirá sor Arcangela Tarabotti - «con prejuicio del libero arbitrio de Su Divina Majestad concedido tanto a los varones como a las mujeres cierran con engaño forzadamente entre las cuatro paredes de un monasterio a mujeres inocentes. [...] Por eso vuelvo a replicar que el pretender quitar la libera volontà a la mujer es contraponerse a la determinación del Omnipotente» ${ }^{99}$. Y en otro pasaje: "pero tú con violencia, insultos y amenazas quieres atar los cuerpos de aquellas que nacieron libere al confinarlas para siempre en un sitio [...] y disponer de la voluntad de aquellas, que no menos que tú poseen la prerrogativa del libero arbitrio, que no puede ser eliminado si no por la muerte» ${ }^{100}$. El léxico de la libertad de la voluntad y de la igualdad de los sexos pertenece a una de las más encendidas polemistas políticas del Seiscientos contra los padres de familia y los padres de la República, pero serpentea en los conventos haciendo emerger así la conciencia de las profesiones forzadas.

96. Cit. en San Martino De Spucches: Storia dei feudi, vol. VIII, cit., p. 183.

97. Jacobson Schutte: By Force and Fear, cit., pp. 158 e 172.

98. Ibid, p. 255.

99. Tarabotti: La semplicità ingannata, cit., pp. 179 e 191, cursiva mía.

100. Ibid, p. 253, cursiva mía. 
Conozco el riesgo de una lectura simplista de las fuentes judiciales, producidas con un objetivo apremiante y práctico y no para la efusión del ánimo de quien produce una instancia, un memorial, una súplica, un testimonio. Aquí el inner feeling de Anna Valdina puede deducirse de su obstinada exteriorización de la voluntad de la profesión que la obliga para toda la vida y le hace poner en marcha una estrategia eficaz para sacarla del convento. Ciertamente su proyecto se aprovecha de los consejos, asistencia, relaciones y posiciones institucionales de quien se beneficiará de su patrimonio, pero esto le permite imponer su condición de heredera y el derecho a elegir al sucesor de su casa. Una cuestión no secundaria de la cultura nobiliaria de la época, plenamente compartida por Anna. El 30 de junio de 1698, habíamos visto a Vittoria Valdina del Bosco, de setenta y siete años, testificando a favor de la sobrina, citar las palabras de su hermano, el príncipe Andrea, según el cual la profesión de la hija «era necesaria para la conveniencia de [su] casa» y la misma motivación había oído pronunciar a Giovanni, el cual «por sus conveniencias y por su decoro estaba obligado a mantenerla [a su hermana] en el monasterio» ${ }^{101}$. Según la vieja noble, Andrea obligó también a sus otras hijas a entrar en el convento de la Abadía nueva, donde murieron casi desesperadas; sacó solo a Felice porque había enfermado mucho "por la pena» para morir poco después. La opinión del príncipe, transmitida al heredero varón, era la «de avanzar su casa en el primogénito y no disminuirla de la facultad con donaciones a las hijas» ${ }^{102}$ y por esta razón solo había permitido a Antonia casarse con un caballero, Marcello Garraffa, «viejo enfermizo que se contentó con poca dote»; si no hubiera sido así, también esta hija habría acabado probablemente en el convento. Un matrimonio con un viejo, enfermizo, de pocas pretensiones, un caballero sin títulos nobiliarios, permite, aunque sea a costa del desclasamiento, solo a una de ellas huir del claustro. Las dotes monásticas son notablemente inferiores a las matrimoniales y, como aquellas, pueden ser pagadas a plazos. Laura y Caterina se quedan en la Abadía nueva -la primera había sido abadesa- hasta la muerte (ocurrida respectivamente en 1653 y en 1659 , por tanto ambas en edad temprana); también Giovanna permanece en el monasterio de la Concepción hasta su muerte, ocurrida en 1685. La estricta lógica patrilineal que con el mayorazgo transmite la totalidad del patrimonio al primogénito, por un lado, deshereda a las mujeres, por otro, acaba por penalizar la estrategia sucesoria de los Valdina que, defendiendo enérgicamente la integridad del patrimonio del asalto de las dotes matrimoniales de las cinco hijas, quedan sin descendencia directa. El segundogénito Carlo, en quien había recaído el título de marqués de la Rocca, no tuvo hijos de su mujer Caterina Mendoza y Sandoval, pero sí un «hijo espurio», Giovanni Battista Valdina,

101. Testes recepti et examinati por el Tribunal de la Regia Monarquía, vol. 165, c. 182v.

102. Íbidem, vol. 165 , c. $184 \mathrm{v}$. 
quien se licencia en derecho y se dedica a los estudios literarios. Recibe del padre por derecho hereditario los títulos y los otros bienes de la familia, pero en 1695 muere en Mesina con apenas cincuenta años. ${ }^{103}$ Caterina, una vez sola, en 1684 funda en la ciudad del estrecho el monasterio de Santa Teresa al cual deja heredero de todos sus bienes ${ }^{104}$. El tercer hijo, Vincenzo, no aparece en la documentación consultada y no conozco su destino.

Queda una pregunta: si comprendemos la elección de Andrea, dirigida a conservar la integridad del patrimonio mediante el primogénito varón, ¿ por qué Giovanni, sin hijos, se resiste con tanta saña a consentir que Anna deje el convento? Debe haberle parecido imperdonable la desobediencia de la mujer al destino elegido para ella con prudencia por la familia y la resistencia opuesta desde niña y durante toda su vida a este destino; las otras hermanas padecen melancolía, se resignan, enferman y mueren, pero no crean escándalo; el escándalo está en la rebelión a los deberes hacia la familia y en la desobediencia a su autoridad. La visita a le Stimmate de Jaime Palafox para persuadir a las monjas para elegir a Anna abadesa parece, desde este punto de vista, como la promesa a Anna de una carrera dentro del convento que, implícitamente, habría equivalido a la aceptación de este destino. Anna, a conciencia, lo rechaza. Giovanni, sin hijos, había elegido como heredera a su propia alma, poniendo la prelatura bajo la protección de la Santa Sede; Anna, en la orgullosa conciencia de su nacimiento y de los privilegios vinculados a este, elige como heredero al estratega de la empresa de hacer declarar nula su profesión, el objetivo de toda su vida. Un pariente, no obstante. La lógica de la sangre, repudiada por el hermano, que opta por una "parentela espiritual», es asumida por ella a quien los consanguíneos han condenado a la esterilidad. Quiero subrayar la pertenencia del donatario a la rama materna: don Ugo es sobrino de la abuela materna, un Papé y no un Valdina; la mujer impone de ese modo la bilateralidad en la descendencia, rechazando la exclusivamente agnaticia. Asume para sí y ejercita el poder de elegir a su aliado como su sucesor. Una estrategia clarividente y subversiva con el «derecho feudal siciliano» que prefiere la continuación de la «línea masculina», haciendo a jovencísimas herederas casarse con el anciano tío paterno ${ }^{105}$.

103. Una breve biografía con la indicación de dos operetas -una oración fúnebre para Giovanni Ventimiglia y un discurso sobre la «falaz esperanza de encontrar la felicidad en la cognición de las buenas disciplinas»-se encuentra en Mongitore, Antonino: Bibliotheca Sicula. Panormi. 1708, t. I, p. 337.

104. El testamento fue rogado en 1693; en 1733 el monasterio vende el título de marqués de Valdina a Paolo Giannotti, barón de Calattubo. De Spucches: Storia dei feudi, cit., vol. VIII, p. 186.

105. Como en el caso de Anna Maria Valguarnera, en Morreale, Antonino: Famiglie feudali nell'età moderna. I principi di Valguarnera. Palermo, Sellerio, 1995. 
Poco o nada sabemos de cómo Anna ha conciliado la personal fe religiosa con la larga reclusión monástica; sabemos que estaba inquieta, su ánimo no correspondía con su condición; ¿ cómo se concilia, por otra parte, la fe con el infierno monacal? Percibimos algunos momentos particularmente dolorosos: en el monasterio se siente desesperanzada, reconoce que si hubiera permanecido allí, habría muerto condenada, como es seguro que murió el padre condenado por haberla metido allí. Otra vez declara que si permanece en el convento, el alma de su padre no podrá dejar el purgatorio. Las relaciones con su hermano se tiñen de agresividad, lo insulta: «el perro luterano de mi hermano» y este a su vez usa el mismo epíteto contra ella: «aquella perra de mi hermana». En el locutorio, un día Anna había pedido a su hermano que la acogiera en su casa, donde se habría metido en un rincón (ad un agnone) y le habría «servido como esclava», y nunca le habría pedido casarse; el hermano la exhortaba a que tuviera respeto de sí misma, a no decir cosas sin sentido, que «quien entra en un monasterio, allí debe morir» ${ }^{106}$. Giovanni habría debido recortar una pequeña parte de su casa para destinarla a Anna, que habría estado confinada, pero habría podido gozar de los servicios y de las comodidades de una casa patricia, en una condición «no demasiado diferente a la de las viudas en las casas de los hijos» ${ }^{107}$. Él se niega a abordar un problema que considera resuelto para siempre por su padre ( $« \mathrm{Si}$ mi padre le obligó a hacerse monja a la fuerza, enfádese con él» ${ }^{108}$ ); ya no es asunto suyo y se lava las manos. La hostilidad hacia la condición monástica, las superiores, los religiosos de la Sacra Congregación de los obispos que obstaculizan la restitución al estado laico, no parece producir, a juzgar por el testamento, un enfriamiento del sentimiento religioso, ni un alejamiento de la iglesia ni de sus enseñanzas. Anna sale del monasterio el 1 de agosto de 1699 a los sesenta y cinco años, después de cuarenta y nueve años de velo -como ya he dicho- y muere el 2 de agosto de 1702; el 15 de junio de 1702, había hecho testamento solemne: había ya hecho acto de donación a Ugo Papé, muerto en 1701 y ahora nombra como heredero universal a Giuseppe Papé y Montaperto, hijo de Ugo. Pide ser enterrada en la iglesia de la Gancia, deja legados para la celebración de su funeral, para las misas por el sufragio de su alma, dispone un centenar de antorchas para los religiosos presentes en su entierro, 200 onzas para otras tantas misas, pequeños legados vita natural durante a cinco profesas de su ex monasterio y a una educanda del monasterio de Montevergini, el aceite para la lámpara del altar de San Francisco del monasterio delle Stimmate, no olvida a los camareros, los sobrinos Domenico e Ignazio Papé, la duquesa de Giampilieri, su criada, el paje, el lacayo a quien lega

106. Testes recepti et examinati, 28 de febrero de 1695, vol. 164, cit., c. $63 \mathrm{v}$.

107. Borello: Il posto di ciascuno, cit., p. 95.

108. Testes recepti et examinati, 28 de febrero de 1695, vol. 164, cit., íbidem. 
pequeñas sumas de dinero, el manto, el jubón, camisas, cojines y un fardel. Ha decidido sobre su vida, sobre sus bienes, ha contradicho la voluntad de su padre Andrea y de su hermano Giovanni, ella una mujer, una monja imbécil, temerosa y pusilánime, pero siempre orgullosa princesa de la casa Valdina.

\section{BIBLIOGRAFÍA CITADA}

ALBERIGO, Giuseppe et al. (ed.): Conciliorum Ecumenorum Decreta. Bolonia, Dehoniane, $1991^{3}$.

Arenaprimo, Giuseppe: Gli esuli messinesi dal 1636 al 1674. Mesina, 1900.

Auria, Vincenzo: «Memorie varie di Sicilia nel tempo della ribellione di Messina», en Gioacchino Di Marzo (ed.): Biblioteca Storica e Letteraria di Sicilia. Vol. VI, Palermo, 1870 (rist. anastatica Bolonia, Forni, 1973)

Borello, Benedetta: Trame sovrapposte. La socialità aristocratica e le reti di relazione femminili a Roma (XVII-XVIII secolo). Nápoles, ESI, 2003.

Bride, André: «Femme», en Catholicisme, vol. IV, París, 1956, col. 1174 y ss.

Calino, Cesare, SJ: Discorsi scritturali e morali ad utile intrattenimento delle monache. Venecia, 1707.

Chiaramonte, Socrate: «La rivoluzione e la guerra messinese del 1674-1678», Archivio Storico Siciliano, 1899, pp. 547-548; Arenaprimo, Giuseppe: Gli esuli messinesi dal 1636 al 1674. Mesina, 1900.

Dalla Torre, Giuseppe: «Imbecillitas sexus e confessio in judicio dei coniugi nelle valutazioni della canonistica classica», Archivio giuridico, 1983, vol. CCIII, fasc. 1-2-3, pp. 31-52.

D’Avenia, Fabrizio: La Chiesa del re. Monarchia e Papato nella Sicilia spagnola (secc. XVI-XVII). Roma, Carocci, 2016.

Diderot, Denis: La religieuse. París, Librairie A. Lemerre, 1925.

Fazio, Ida: La politica del grano. Annona e controllo del territorio in Sicilia nel Settecento. Milán, Franco Angeli, 1993.

Fodale, Salvatore: L'Apostolica Legazia e altri studi su Stato e Chiesa. Mesina, Sikania, 1991.

Giarrizzo, Giuseppe: «La Sicilia dal Cinquecento all'Unità», en Vincenzo D’Alessandro y Giuseppe Giarrizzo: La Sicilia dal Vespro all'Unità d'Italia. Turín, UTET, 1989.

Jacobson Schutte, Anne: «Between Venice and Rome: the Dilemma of Involuntary Nuns», Sixteenth Century Journal, XLI/2, 2010, pp. 415-439.

Jacobson Schutte, Anne: By Force and Fear. Taking and Breaking the Monastic Vows in Early Modern Europe. Ithaca y Londres, Cornell University Press, 2011.

Königsberger, Helmut G.: «The revolt of Palermo in 1647», The Historical Journal, n. 8, 1946, pp. 129-144.

Laudani, Simona: La Sicilia della seta. Economia, società, política. Roma, Donzelli, 1996 .

Laven, Mary: Monache. Vivere in convento nell'età della Controriforma. Bolonia, Il Mulino, 2004. 
Leclerq, Henri: «Femme» en Dictionnaire d'archéologie chrétienne et de liturgie, vol. V, París, 1922, col. 1300 y ss.

Lett, Didier: «Prefazione» a Benedetta Borello: Il posto di ciascuno. Fratelli, sorelle e fratellanze (XVI-XIX secolo). Roma, Viella, 2016.

Lirosi, Alessia: I monasteri femminili a Roma tra XVI e XVII secolo. Roma, Viella, 2012.

Lombardi, Daniela: Storia del matrimonio dal Medioevo a oggi. Bolonia, Il Mulino, 2008.

Mango di Casalgerardo, Antonino: Nobiliario di Sicilia. Palermo, Reber, 1912.

Manzoni, Alessandro: I promessi sposi. Milán, Mondadori, 2009.

Medioli, Francesca: «Monacazioni forzate: donne ribelli al proprio destino», Clio. Rivista trimestrale di Studi storici, A. XXX, n. 3, 1994.

Medioli, Francesca: «Lo spazio del chiostro: clausura, costrizione e protezione nel XVII secolo", en Silvana Seidel Menchi, Anne Jacobson Schutte, Thomas Kuehn (ed.): Tempi e spazi di vita femminile tra Medioevo ed età moderna. Bolonia, Il Mulino, 1999.

Morreale, Antonino: Famiglie feudali nell'età moderna. I principi di Valguarnera. Palermo, Sellerio, 1995.

Napoli, Maria Teresa: La Regia Monarchia di Sicilia. "Ponere falcem in alienam messem». Nápoles, Jovene, 2012.

Oddo, Francesco D.: Dizionario di antiche istituzioni siciliane, Palermo, Flaccovio, 1983.

Palermo, Daniele: Sicilia 1647: voci, esempi, modelli di rivolta. Palermo, Associazione Mediterranea, 2009.

Paolin, Giovanna: Lo spazio del silenzio. Monacazioni forzate, clausura e proposte di vita religiosa femminile nell'età moderna. Pordenone, Edizioni Biblioteca dell'Immagine, 1996.

Piangatelli, Gualberto: «La forzata scelta della vita ecclesiastica o religiosa nei secoli XVI-XVIII e l'atteggiamento della Chiesa locale», en AA. VV., La nobiltà della Marca nei secc. XVI-XVII. Patrimoni, carriere, cultura. Macerata, Centro di studi storici maceratesi, 1998.

Prosperi, Adriano: Il Concilio di Trento. Turín, Einaudi, 2001.

Prosperi, Adriano: La vocazione. Storie di gesuiti tra Cinque e Seicento. Turín, Einaudi, 2016.

Ribot García, Luis: La revuelta antiespañola de Mesina. Valladolid, Universidad de Valladolid, 1982.

Ribot García, Luis: La Monarquía de España y la guerra de Mesina (1674-1678). Madrid, Editorial ACTAS, 2002.

San Martino De Spucches, Francesco: Storia dei feudi e dei titoli nobiliari di Sicilia. Vol. VIII, Palermo, 1933, pp. 180-185.

Siciliano, Anna: «Sulla rivolta di Palermo del 1647», Archivio storico siciliano, 1939, pp. 183-30.

Tarabotti, Angela: Inferno monacale, en Francesca Medioli: L' "Inferno monacale» di Arcangela Tarabotti. Turín, Rosenberg \& Sellier, 1990.

Tarabotti, Angela: La semplicità ingannata. Ed. crítica editada por Simona Bortot, Padua, Il Poligrafo, 2007. 
Testa, Giuseppe: Suor Francesca, principessa e monaca nel monastero della Badia nuova di Palermo. Palermo, Flaccovio, 1976.

Trasselli, Carmelo: «Messina 1674», en AA. VV.: La rivolta di Messina (1674-1678) e il mondo mediterraneo nella seconda metà del Seicento. Actas del Congreso, Messina, 1975.

Verga, Giovanni: Storia di una capinera. Milán, Feltrinelli, 2001.

Villari, Rosario: «La rivolta di Messina e la crisi del Seicento», en Saverio Di Bella (ed.): La rivolta di Messina (1674-1678) e il mondo mediterraneo nella seconda metà del Seicento. Cosenza, Luigi Pellegrini Editore, 2001, pp. 29-42.

Vismara Chiappa, Paola: Per vim et metum. Il caso di Paola Teresa Pietra. Como, Litografia New Press, 1991.

Zanetti, Dante E.: «La demografia del patriziato milanese nei secoli XVII, XVIII, XIX», Annales Cisalpines d'histoire sociale, II serie, n. 2, 1972.

Zarri, Gabriela: Recinti. Donne, clausura e matrimonio nella prima età moderna. Bolonia, Il Mulino, 2000.

Zito, Gaetano: «Sicilia», en Id. (ed.), Storia delle Chiese di Sicilia. Ciudad del Vaticano, Libreria Editrice Vaticana, 2009.

Zorzi, Alvise: La monaca di Venezia. Una storia d'amore e di libertà. Milán, Mondadori, 1996.

Ediciones Universidad de Salamanca / 요 Stud. his., H. ${ }^{a}$ mod., 40, n. 2 (2018), pp. 31-62 